


\section{DISCLAIMER}

This report was prepared as an account of work sponsored by an agency of the United States Government. Neither the United States Government nor any agency Thereof, nor any of their employees, makes any warranty, express or implied, or assumes any legal liability or responsibility for the accuracy, completeness, or usefulness of any information, apparatus, product, or process disclosed, or represents that its use would not infringe privately owned rights. Reference herein to any specific commercial product, process, or service by trade name, trademark, manufacturer, or otherwise does not necessarily constitute or imply its endorsement, recommendation, or favoring by the United States Government or any agency thereof. The views and opinions of authors expressed herein do not necessarily state or reflect those of the United States Government or any agency thereof. 


\section{DISCLAIMER}

Portions of this document may be illegible in electronic image products. Images are produced from the best available original document. 


\section{DISCLAIMER}

This report was prepared as an account of work sponsored by an agency of the United States Government. Neither the United States Government nor any agency thereof, nor any of their employees, makes any warranty, express or implied, or assumes any legal liability or responsibility for the accuracy, completeness, or usefulness of any information, apparatus, product, or process disclosed, or represents that its use would not infringe privately owned rights. Reference herein to any specific commercial product, process, or service by trade name, trademark, manufacturer, or otherwise, does not necessarily constitute or imply its endorsement, recommendation, or favoring by the United States Government or any agency thereof. The views and opinions of authors expressed herein do not necessarily state or reflect those of the United States Government or any agency thereof.

Printed in the United States of America Available from the National Technical Information Service

U.S. Department of Commerce Springfield, Virgina 22161

Page Range

Domestic Price*

001025

026-050

051-075

076-100

$\$ 6.00$

7.50

101-125

9.00

10.50

12.00

*All microfiche are priced at $\$ \mathbf{5 5 . 0 0}$

Prices Subject to Change Without Notice 
Printed

March 10, 1982

RFP -3186

DE82 013228
RFP-3186

UC-70 NUCLEAR WASTE

MANAGEMENT

DOE/TIC 4500 (Rev. 69)

\section{HISTORY OF RDCKY FLATS WASTE STREAMS}

Lori L. Luckett

Alice A. Dickman

Charlene R. Wells

Donald J. Vickery

R. D. Howerton, Editor

G. Shekell, Compositor

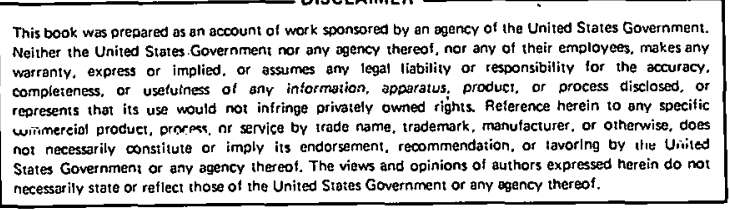

States Government or any agency thereot. The viaws and opinions of authors expressed
necessasily state or reflect those of the United States Government or any ggency thereof.

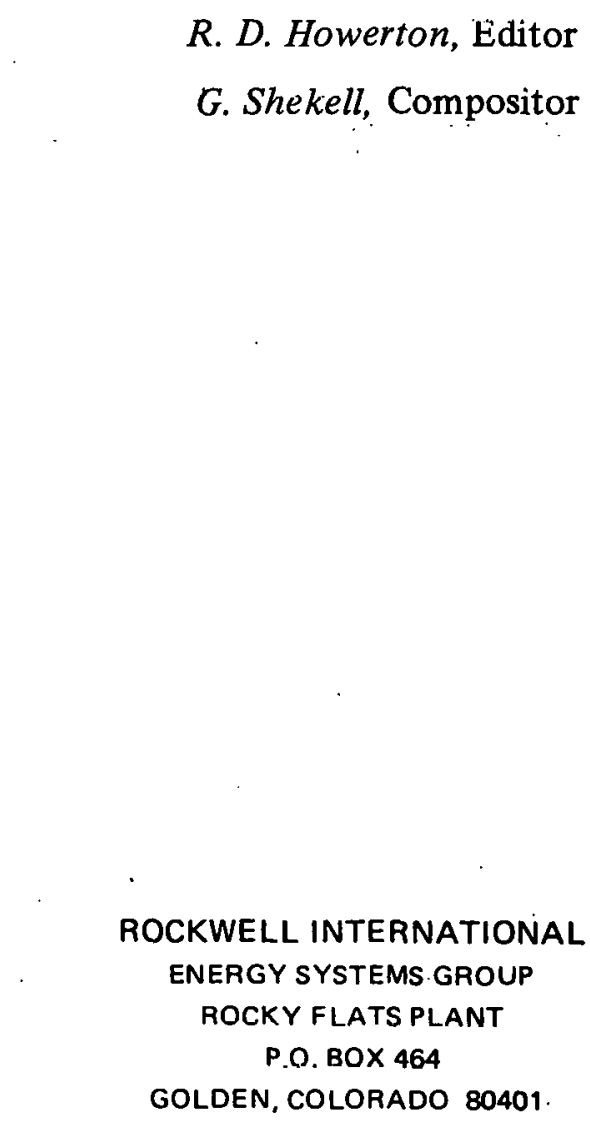

SUBJECT DESCRIPTORS

Transuranic Waste WIPP

Prepared under Contract DE-AC04-76DPO3533

for the

Albuquerque Operations Office

U.S. Department of Energy

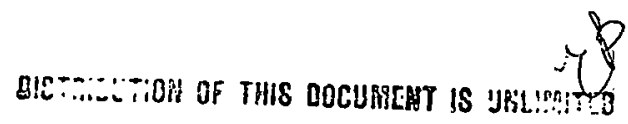




\section{CONTENTS}

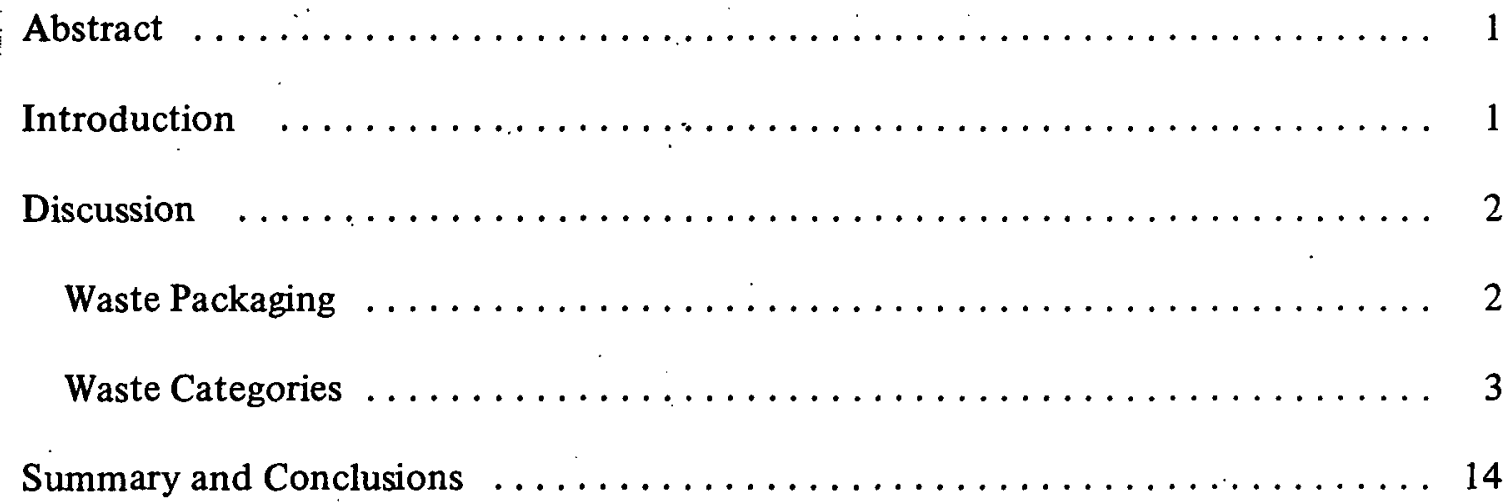

Appendix A - Tabulated Summaries of Major Waste Categories Shipped to INEL $\ldots 15$ Appendix B - Rocky Flats Content Codes and Descriptions $\ldots \ldots \ldots \ldots \ldots$ 
RFP-3186

\title{
HISTORY OF ROCKY FLATS WASTE STREAMS
}

\author{
Lori L. Lucḱktt, Alice A. Dickman, \\ Charlene R. Wells, and Donald J. Vickery
}

\begin{abstract}
An analysis of the waste streams at Rocky Flats was done to provide information for the Waste Certification Program. This program has involved studying the types and amounts of retrievable transuranic (TRU) waste from Rocky Flats that is stored at the Idaho National Engineering Laboratory (INEL). The information can be used to estimate the types and amounts of waste that will need to be permanently stored in the Waste Isolation Pilot Plant (WIPP). The study covered mostly the eight-year period from Iune 1971 to June 1979. The types, amounts, and plutonium content of TRU waste and the areas or operations responsible for generating the waste are summarized in this waste stream history report.
\end{abstract}

From the period studied, a total of $24,546,153 \mathrm{lbs}$ of waste containing $211,148 \mathrm{~g}$ of plutonium currently occupies $709,497 \mathrm{cu} \mathrm{ft}$ of storage space at INEL.

\section{INTRODUCTION}

The objective of this study was to generate a wastehistory file that would identify and characterize transuranic (TRU) waste produced at the Rocky Flats Plant and stored at the Idaho National Engineering Laboratory (INEL) since 1970. Transuranic waste is prescntly defined as waste contaminated with more that 10 nanocuries of TRU nuclides per gram of waste. This TRU classification was first used in the early 1970's. Most TRU waste originating at Rocky Flats is contaminated with plutonium, with the waste being generated primarily in plutonium fabrication areas and in the chemical processing facility. The Research and Development organization, Plutonium Analytical Laboratorics, and other support groups generate lesser quantities of contaminated waste.
The TRU waste is packaged and shipped for storage at INEL where it is classified as retrievable, awaiting permanent storage in an approved repository. One proposed repository is the Waste Isolation Pilot Plant (WIPP) near Carlsbad, New Mexico. A recently issued Waste Acceptance Criteria (WAC) set forth by WIPP is considered a basis for acceptance of waste in a permanent repository. The study described in this report will aid in determining the certification status of past and present Rocky Flats waste against the WAC.

Internal shipping and handling procedures at the Rocky Flats Plant were obtained to aid in documenting the Plant's waste history. Plant procedures used prior to 1975 for inspecting TRU waste were discarded whenever a new procedure was issued that superseded the previous one. After 1975, the Technical Writing Group was given the responsibility of distributing and upgrading the Plant procedures. Also included in this task was the maintenance of a history copy of the procedures. All shipping and handling procedures prior to 1975 presumably had been destroyed; however, shipping and handling procedures, dated 1971, were found in the Quality Engineering System and Plans Office. These procedures correlated closely with those now in cfficet.

Data on Plant waste shipped off-site for storage was not kept until mid-1971 when a records-keeping effort was begun by Waste Management personnel; consequently, data on waste generation from 1970 to mid-1971 was not incorporated into the computer data base. Much of the data contained in this report was obtained from the Process Control Computer Operations Group. Other information was collected from personnel and records in Production Control, Data Processing, Waste Operations, Nuclear Materials Control, and from area supervisors. While most of the information reported here pertains to the period 1971-1979, current activities also are included. 


\section{DISCUSSION}

Waste Packaging

\section{Container Condition}

All TRU waste shipped from Rocky Flats to INEL during the 1970's was packaged in 30-gal drums, 55-gal drums, $4^{\prime} \times 4^{\prime} \times 7^{\prime}$ boxes and $2^{\prime} \times 4^{\prime} \times 7^{\prime}$ boxes (half boxes). Use of the 30 -gal drums. was discontinued in 1973; however, while they were in use, the 30-gal drums were often packaged inside the 55-gal drums. Prior to 1971 , wooden crates were used for shipping TRU waste from the Rocky Flats Plant to Idaho. In 1971, improved waste packages came into use. These packages consist of plywood boxes coated with fiberglass reinforced polyester (FRP). The coating was applied to the boxes by Rocky Flats personnel until late 1971 when the Plant began purchasing FRP boxes from a vendor. This type of box is still being used. Another change in the acceptable waste shipping containers started in late 1975 when rigid liners were first used in the 55-gal drums.

All containers were and continue to be inspected prior to leaving the Rocky Flats Plant site. The inspection criteria consists of (1) satisfactory condition of container element, (2) absence of free liquids, (3) levels of radioactive contamination control being within Department of Transportation (DOT) and Rocky Flats Plant limits, and (4) waste containers being labeled properly.

Standard procedure for all 55-gal drums and the 2.3-mm-thick molded polyethylene drum liners require a visual inspection by the operator for damage prior to having waste placed in the drums. When a drum is full, the generator contacts Waste Management for disposal. Waste Management is responsible for visually inspecting the drum gasket and drum liner for damage and for final inspection approval of each waste container. After a drum has passed all inspection tests, it is sealed by Waste Management using the following procedure:

1. Place lid on drum

2. Assure gasket is in proper position for an airtight seal
3. Assure bolt is in line with seal

4. Seal.

The boxes are composed of 3/4-inch-thick plywood and are coated with a 3-mm laminate of FRP. This coating serves several purposes. It is a fire retardant, it seals the crate against moisture, and it serves as a support, thus strengthening the crate. Prior to use, the crates are lined with $0.15-\mathrm{mm}$ polyvinyl chloride (PVC) and a 1.3-mm fiberboard to protect the PVC from sharp edges in the waste. The boxes are visually inspected by an operator before he adds any waste. Waste Management personnel then inspect the boxes after they have been filled. To pass inspection, boxes must be judged satisfactory by both the operator and by Waste Management.

\section{Waste Certification - Present Practices}

Free Liquids: Waste Management personnel visually inspect the drums and boxes for free liquids prior to the containers being sealed. The procedure for checking drums has been to place a drum in a horizontal position with the bottom of the drum slightly elevated. This position helps toward determining that the drum contains no free liquids. Sealed drums are opened for this test, and those stored outside at freezing conditions are moved inside for at least 24 hours prior to the free-liquid test. Waste Management performs the free-liquid test as an essential step of overall inspection approval. Containers in which free liquid is present can pass inspection by adding an absorbent such as Oil Dri or cement, depending on the type of waste.

Radioactive Limits: Waste Management, with the aid of personnel from Health, Safety and Environment or from Health Physics, is responsible for measuring the level of radioactivity. All waste receptacles shipped off the Rocky Flats Plant site are subject to alpha and gamma radiation limits. These limits are determined by the Department of Transportation (DOT). The limits are

1. 250 counts per minute of fixed alpha radiation

2. 20 disintegrations per minute of alpha radiation 
3. 200 millirem surface gamma count

Label: Waste Management must also inspect the label of a waste container to ensure that the label is correct. The label contains the following information:

1. content code

2. prefix and/or building and room number of generation

3. radiology test results

4. beryllium content

5. line generated or non-line generated

6. total weight and plutonium content

7. seal date

8. supervisor certification

Each of these will be discussed in turn.

The content code is a three-digit entry that specifically identifies the type of material in the container. Appendix B is a complete listing of content codes used for waste shipped to INEL from Rocky Flats during the period 1971-1979.

Rocky Flats identifies its general stream operations by account numbers. Prefix numbers, which provide a further breakdown of account numbers, are used to identify a specific operation within the general account stream. Since 1970 , prefix numbers have been discontinued when an operation is discontinued; however, the same numbers have sometimes been reassigned to another operation. In cases where one prefix is assigned to more than one operation, the date of the package can separate which operation the prefix is describing. Some labels do not give the prefix; instead, it gives the room and building number where the waste is processed. This serves the same purpose as the prefix; it locates the source of the waste stream.

Radiology tests are checked to make certain that radiation from the waste is within the limits previously described. Beryllium contaminants are noted although there are no shipping limits. The waste also is marked as line generated or non-line generated. Line generated waste is generated in a process, such as plutonium recovery sludge. Nonline generated waste is considered to be suspect waste, such as laundry waste.

The weight and plutonium content are checked to make certain both are within the shipping limits. These limits are as follow:

\begin{tabular}{|c|c|c|}
\hline Container & $\begin{array}{l}\text { Maximum Weight } \\
\text { (lbs) }\end{array}$ & $\begin{array}{l}\text { Maximum Pu Weight } \\
\text { (g) }\end{array}$ \\
\hline 55-gal drum & 800 & 200 \\
\hline 30-gal drum & 800 & 200 \\
\hline $4^{\prime} \times 4^{\prime} \times 7^{\prime}$ box & .5000 & 560 \\
\hline $2^{\prime} \times 4^{\prime} \times 7^{\prime}$ box & 5000 & 280 \\
\hline
\end{tabular}

Although the maximum shipping weight for plutonium in boxes is $5 \mathrm{~g} / \mathrm{cu} \mathrm{ft}$, the rule-of-thumb limit for a box is $350 \mathrm{~g}$. The waste is retrieved if there is more than $350 \mathrm{~g}$ of plutonium in a box. The half-box legal limit is $280 \mathrm{~g}$ of plutonium; however, waste contaminated with large amounts of plutonium is not shipped in half boxes but in the $4^{\prime} \times 4^{\prime} \times 7^{\prime}$ FRP-coated boxes.

The waste package is sealed after Waste Management inspects the package and the shipping label. If the container passes inspection and the labeling information is correct and within shipping requirements, the label is signed and dated.

\section{Waste Categories}

\section{Unleached Light Metals}

The largest waste category is unleached light metals (Content Code 480). This category includes metals such as iron, copper, aluminum, and stainless steel, which are low enough in plutonium content that they are not processed through the leaching process of the plutonium recovery operations in Building 771 . 


\section{RFP-3186}

The total volume of these metals, as shown in Tables 1 and $2,{ }^{*}$ is $308,829 \mathrm{cu} \mathrm{ft}$, which represents 43.5 vol \% of the total waste generated at the Rocky Flats Plant. The overall weight percent is 34.2 and the plutonium is $13.8 \mathrm{wt} \%$.

Table 3 shows the major waste contributors of unleached light metals. Most of the light metals are equipment, such as glove boxes, from all areas of the Rocky Flats Plant. The equipment is too bulky to be stored efficiently, so it is sent to Size Reduction (Prefixes 389, 33, 776**) for compaction and treatment before being shipped to INEL. The major waste contributor to this category of unleached light metals is the Size Reduction area which accounts for $82.1 \%$ of the waste by volume. Plutonium waste having high radiation levels, which accounts for $75.7 \%$ of the plutonium in this category, is packaged in FRP boxes (Prefix 389). Although the equipment has been through Size Reduction, the packaging is still somewhat inefficient, which accounts for the volume percent (43.5) in this category being larger than the weight percent (34.2).

Since 1972, the first year for which complete data are available, there has been a decrease in the volume, weight, and plutonium content in the unleached metals category. These decreases reduced the volume and mass by a factor of 4 . There are two reasons believed to be the cause of these reductions. First, the cleanup of Building 776 after the 1969 fire added a large amount to this category, causing an increase through 1972. Secondly, there was a backlog of metal awaiting treatment prior to shipment, when the discard limits were lowered. This allowed more metal to be transported without treatment.

\section{Combustibles}

Combustibles are divided into two categories, dry (Content Code 330) and wet (Content Code 336). Dry combustibles are the Plant's second largest waste type, by volume, stored at INEL. They account for $72,902 \mathrm{cu} f t$ of waste $(10.3 \mathrm{vol} \%)$ and $1,404,797 \mathrm{lbs}$ of waste (5.7 wt \%).

\footnotetext{
*All tables are presented in Appendix A.

**See Table 3.
}

The major waste sources are shown in Table 4 for dry combustibles and in Table 5 for wet combustibles. Size Reduction accounts for the largest amount of combustible wastes; the Slow NonSpecification Recount (recycle) is the next largest contributor.

There are more sources of combustible waste than unleached light metals for two reasons. First, generation of combustible waste occurs plantwide. Secondly, combustibles are more easily disposed of by individual areas because special treatment is not required, as is the case with unleached light metals.

The amount of dry combustibles generated has increased steadily over the years, and the amount of wet combustibles generated has steadily decreased. There are two apparent reasons for these changes. One is better segregation between wet and dry combustibles. With the addition of a small amount of wet combustibles to a package containing dry combustibles, the package has been reclassified as wet combustibles. The second reason is that dry combustibles generally are below the discard limit and therefore are more easily disposed of. The wet combustibles, in contrast, are usually above the discard limit and therefore more difficult to dispose of.

Waste that contains low amounts of plutonium or waste that contains no plutonium but is generated in a plutonium production area is considered TRUsuspect waste and is handled in the same manner as other TRU wastes with higher amounts of contaminants. The dry combustible category consists primarily of suspect waste.

\section{HEPA Filters}

High Efficiency Particulate Air (HEPA) filters (Content Code 490) are used throughout the Plant and are the third largest volume contributor, with $8.9 \mathrm{vol} \%$ of the total waste. Table 6 shows the sources of the HEPA filters. Since thes $\epsilon$ filters are bulky and inefficient for shipping, they are sent from production areas of the Plant to Size Reduction which accounts for $6.2 \mathrm{vol} \%$ of the overall waste $(44,057 \mathrm{cu} \mathrm{ft})$ and $12.5 \mathrm{wt} \%$ of the waste 
$93.9 \mathrm{vol} \%$ of all filters, a total of $59,472 \mathrm{cu} \mathrm{ft}$. The filters with higher plutonium content are packaged in FRP boxes, which account for 84.4 vol \% of the total HEPA filter waste. Filters collected during a PuF cleanup following the 1969 fire are another source of HEPA filters and account for $2.0 \mathrm{vol} \%$ of the total filter waste.

Plutonium weight remains fairly constant as do the percentage contribution of HEPA filters to the total waste in each year. The yearly weight and volume of HEPA filters decreased, however, over the years studied. There are several reasons for this decrease. The building fire in 1969 caused the total HEPA filter disposal to be high through 1972 because the plenums were rebuilt and all of the old filters were discarded. Also, during the early 1970's; several building filtering systems were upgraded, which resulted in high totals during 1973 and 1974.

\section{$\underline{\text { Plutonium Recovery Wastes }}$}

Four of the major TRU waste categories stored at INEL from Rocky Flats are liquid wastes from the plutonium recovery operations that have been treated to form a sludge-a solid suitable for shipping. Waste liquids are collected through process drain networks and stored in holding tanks in the process areas. These tanks are sampled to determine what subsequent treatment is required. The liquid waste is then transferred by pipeline or by truck to the appropriate treatment tank. In certain cases, such as R\&D laboratories that generate small amounts of contaminated liquid, the liquid is accumulated in suitable containers and transferred by truck to the treatment area. The TRU liquid waste categories are

\section{First Stage Sludge - Content Code 1 \\ Second Stage Sludge - Content Code 2 \\ Grease - Content Code 3 \\ Special Setups - Content Code 4}

The first stage of the solidification operation is a chemical precipitation of radioactive elements from the liquid waste. The chemicals used are fèrric sulfate, calcium chloride, magnesium sulfate, and coagulates. The resulting sludge, categorized as first stage sludge, is filtered and discarded into a drum. The sludge in each drum is then sampled and analyzed for radioactive material content. First stage sludge is packed with cement that absorbs any free liquids.

Effluent from the first stage treatment is filtered and sent to the second stage batch process where it is . mixed with high-nitrate radioactive materials. The same chemicals used in the first stage chemical precipitation process are used for precipitation in the second stage. The second stage batch process handles radioactive high-nitrate waste. Radioactive low-nitrate wastes are treated in a continuous process that is similar to the batch process in treatment, filtration, packaging, and sampling. The resulting precipitate is packaged in drums with cement and referred to as second stage sludge. Samples of second stage sludge are taken at random intervals during the shift and are analyzed for radioactive materials. Effluent from the second stage treatment unit is sampled to ensure that radioactivity limits are met. The effluent is then transferred to evaporation ponds for concentration of the nitrate solution.

Contaminated liquid wastes that are not compatible with the chemical precipitation and evaporation treatments are solidified by mixing the liquids with a cement absorbent. The liquid waste is made into a basic solution and put into a drum that contains the absorbent mixture. The moisture is absorbed by the cement mixture, which then hardens to form a solid mass suitable for shipping. These waste drums are called Special Setups.

Organic liquid wastes, such as contaminated lathe coolant, are transferred from process areas to Building 774 feed tanks for the organic solidification line. These wastes are then mixed with solidifying agents to form a dry solid that is discharged into 55-gal drums. The resultant product is categorized as Grease.

Second stage sludge is the fourth largest category of waste shipped from Rocky Flats for storage at INEL. (See Table 1.) It accounts for $46,351 \mathrm{cu} \mathrm{ft}$ (6.5 vol \%) and 3,385,472 lbs (13.8 wt \%). The next largest waste contributor is first stage sludge, 
which accounts for 6.2 vol $\%$ of the overall waste $(44,057 \mathrm{cu} \mathrm{ft})$ and $12.5 \mathrm{wt} \%$ of the waste $(3,073,238 \mathrm{lbs})$. The plutonium content of first stage sludge is about 15 times greater than that of second stage sludge. This is expected since it is the primary plutonium removal treatment. Grease follows first stage sludge with $4.4 \mathrm{vol} \%$ and $9.2 \mathrm{wt}$ $\%(30,289 \mathrm{cu} \mathrm{ft}$ and $2,228,119 \mathrm{lbs}$, respectively). Special Setups contribute $1.1 \mathrm{vol} \%$ and $2.7 \mathrm{wt} \%$ of the total waste $(7,739 \mathrm{cu} \mathrm{ft}$ and $653,876 \mathrm{lbs}$, respectively).

Tables $7,8,9$, and 10 show the sources of second stage sludge, first stage sludge, grease, and special setups, respectively. It would seem logical to expect all of the first stage sludge to come from the first stage liquid waste treatment area and similarly the other wastes to come from their area. Although the vast majority of the wastes (more than $99.9 \%$ ) do this, there are a few drums that do not conform to this expectation. There is no reasonable explanation for this, and a labeling error is assumed to be the explanation.

The percent of yearly waste remains relatively unchanged over the years studied. This indicates an overall decreased production of waste at the Rocky Flats Plant during the years highlighted in this report (1971-1979).

\section{Blacktop, Concrete, Dirt, and Sand}

Content Code 374 includes dirt, concrete, blacktop, and sand that have been excavated for construction work. This accounts for $23,517 \mathrm{cu} \mathrm{ft}$, or $3.3 \mathrm{vol} \%$ of the TRU waste generated at Rocky Flats and stored at INEL. Sources of this waste are shown in Table 11. The largest source of this waste category, $68.8 \mathrm{vol} \%$, is material from the lip area beside the blacktop pad that covers contaminated soil near the east gate of the Rocky Flats Plant. This does not contain a detectable amount of plutonium weight. Size Reduction areas account for 20.9 vol \% of the waste, $7.6 \%$ of this being packaged in FRP boxes.

The remaining $10.3 \mathrm{vol} \%$ comes from such sources as maintenance, laundry, and utility areas. The liquid waste treatment area and the slow side of the plutonium recovery area in Building 771 are also contributors, as well as other areas. All waste in the dirt, concrete, blacktop, and sand category was collected from 1973 to 1977 . Most of this was collected in 1976 and 1977 when excavation around the blacktop pad was performed.

\section{Plastics and Non-Leaded Rubber}

Plastics [e.g. polyvinyl chloride (PVC), teflon, and vinyl] and non-leaded rubber are grouped together under Content Code 337. These materials contribute $11,948 \mathrm{cu}$ ft to the TRU waste shipped for storage at INEL from Rocky Flats. This quanity represents $1.7 \mathrm{vol} \%, 1.2 \mathrm{wt} \%$, and 1.0 plutonium weight percent of all TRU waste from Rocky Flats during the 8 yrs studied. (See Table 1.)

Table 12 shows the major sources of plastics from the Rocky Flats Plant. The Special Setup operations of the liquid waste treatment facilities in Building 774 account for 25.5 vol \% of the plastic waste. The slow recycle (recount) side of the plutonium recovery facilities accounts for $14.7 \mathrm{vol}$ $\%$, the fast side accounts for $3.2 \mathrm{vol} \%$, and the Size Reduction areas account for 15.9 vol \% of the plastics. The laboratories and chemical operations in Building 771 supply another $10.5 \mathrm{vol} \%$, and $7.6 \mathrm{vol} \%$ is attributed to maintenance, laundry, and utilities. Of the remaining sources of plastics and unleaded rubber, each source contributes less than $1 \mathrm{vol} \%$ to the total quantity of waste in this category. The diversity of the sources of plastics show that plastics, like wet and dry combustibles, are an easily handled waste form; therefore they are not sent to Size Reduction for treatment prior to shipping.

The volume, weight, and plutonium weight of plastics and unleaded rubber, as well as their respective percentages of the yearly waste, have decreased steadily over the years.

\section{$\underline{\text { Raschig Rings }}$}

Raschig rings used at Rocky Flats are hollow glass cylinders containing boron, a neutron absorber. Raschig rings are used in liquid-holding tanks in various areas of the Plant, and serve to prevent 
criticality in liquid solutions that have a high concentration of neutron-emitting particles, such as plutonium. Raschig rings that contain insufficient amounts of plutonium to warrant recovery are packaged as waste without any pretreatment. These rings are grouped together in Content Code 441 (Unleached Raschig Rings). Unleached Raschig rings account for $11,390 \mathrm{cu} f \mathrm{ft}$ of the waste stored at INEL from Rocky Flats. This amount represents $1.6 \mathrm{vol} \%, 1.2 \mathrm{wt} \%$, and 5.9 plutonium weight percent.

Major waste contributors of unleached Raschig rings are given in Table 13. The major contributors are the plutonium recovery areas (Prefix Codes 2 and 5), which accounts for $74.6 \mathrm{vol} \%$ of this category. The remaining $25.4 \%$ of the Raschig rings come from areas that include the R\&D Chemistry Laboratory's process waste, R\&D liquid, Building 707 Foundry Operations, and Size Reduction areas.

An increase in unleached Raschig rings shipped from Rocky Flats to INEL in 1973 resulted from a change in Nuclear Safety rules at Rocky Flats requiring that Raschig rings be changed more often. In 1975 the discard limits were changed, and Raschig rings that earlier would have undergone treatment prior to storage were shipped without treatment. Since 1975 , the volume of Raschig rings has been decreasing, corresponding to the decreased generation of plutonium production solutions.

Insulation and Chemical Warfare Service Filter Media

A total of $10,402 \mathrm{cu} \mathrm{ft}$ ( $1.5 \mathrm{vol} \%$ of insulation and Chemical Warfare Service (CWS) filter media (Content Code 338) was shipped between 1971 and 1976 from Rocky Flats for storage-at INEL.

The sources of insulation and CWS filter media are shown in Table 14. Size Reduction areas account for $84.0 \mathrm{vol} \%$ of this category. Only $17.2 \mathrm{vol} \%$ of this waste category is packaged in FRP boxes, indicating a low plutonium lcvel; $11.3 \mathrm{vol} \%$ is from Building 771 Plutonium Recovery-Slow Side (Prefix 2).
The insulation and CWS filter media category contributed approximately 4 vol \% of the total yearly waste in 1973 and 1974. In 1972, 1975, and 1976, small quantities of this waste category were found in the yearly waste stream. After 1976, this category was completely phased out and the waste was incorporated into cemented insulation and filter media, Content Code 376.

Other Waste Types

All of the waste categories, divided by content codes, that contribute more than $1.0 \mathrm{vol} \%$ of the total Rocky Flats TRU waste stored at INEL have been tabulated and discussed previously in this report. The "other" waste categories, collectively, contribute $8.4 \mathrm{vol} \%, 8.5 \mathrm{wt} \%$, and 50.8 plutonium weight percent to the total waste. The waste is classified into the more narrow categories of glass, brick and concrete, graphite, dirt and sludges, filters, metal, hard and soft LSA* material, resins, ash, rubber, and salt, as shown in Table 2. These are listed in order of decreasing volumes.

\section{SUMMARY AND CONCLUSIONS}

All waste packaged for storage must pass inspection before being shipped off the Rocky Flats Plant site. This inspection ensures that the containers are in satisfactory condition, there are no free liquids present, the levels of radioactive contamination are within specified limits, and that the container is properly classified and labeled. This waste, having met all criteria, is then shipped to INEL for storage until the proposed repository is completed. With the storage data now computerized, coupled with content codes and prefixes, it is significantly easier to discover the type of material packed in a specific container, where that waste stream originated, the primary contaminants and their weight, the weight of the container, and the date the container was shipped for storage.

*LSA - Low Specific Activity. This term is defined under Content Code 900 and 950 in Appendix B. 
Waste shipped from Rocky Flats to INEL for storage has been categorized by the type and source of the waste. This report summarized the volumes, weights, and plutonium weights of the waste by categorizing the waste into groups having similar content. Within the groups that categorize the waste by type, this report sub-categorizes the waste by its source (prefix). The Computer Center can provide information on any combination of content code and prefix. Over the years, the amount of TRU waste shipped for storage at INEL from Rocky Flats has decreased steadily in volume, weight, and plutonium weight. 


\title{
APPENDIX A
}

\section{Tabulated Summaries of Major Waste \\ Categories Shipped to INEL}

\begin{abstract}
Appendix A contains summaries, in tabular form, of the waste stream categorics scnt to INEL for storage from June 1971 to June 1979. Table 1 shows the volumes, weights, and plutonium weights of TRU waste shipped from Rocky Flats to INEL by classification of waste type in order of decreasing volume. Table 2 shows the generalized breakdown of waste classified as "Other" in Table 1, also in the order of decreasing volume. Tables 3-14 show the major sources of each waste stream of the major waste category, again in the order of decreasing volume.
\end{abstract}

Volume and volume percent of the major waste categories are by calendar year in Table 15. Table 16 shows the content weight and weight percent by calendar year. Mass and mass percent of the waste by calendar year is shown in Table 17. 


\section{RFP-3186}

TABLE 1. Major Waste Categories Shipped to INEL from Rocky Flats Plant 1971-1979

\begin{tabular}{|c|c|c|c|c|c|c|c|}
\hline $\begin{array}{c}\text { Content } \\
\text { Code } \\
\end{array}$ & $\begin{array}{c}\text { Content } \\
\text { Type } \\
\end{array}$ & $\begin{array}{c}\text { Volume } \\
\text { (cu ft) }\end{array}$ & $\begin{array}{c}\text { Volume } \\
(\%) \\
\end{array}$ & $\begin{array}{c}\text { Weight } \\
\text { (bs) }\end{array}$ & $\begin{array}{c}\text { Weight } \\
(\%) \\
\end{array}$ & $\begin{array}{c}\text { Pu Weight } \\
\text { (g) }\end{array}$ & $\begin{array}{c}\text { Pu Weight } \\
\quad \%) \\
\end{array}$ \\
\hline 480 & Unleached Light Metals & 308,829 & 43.5 & $8,386,295$ & 34.2 & 29,194 & 13.8 \\
\hline 330 & Dry Combustibles & 72,902 & 10.3 & $1,404,797$ & 5.7 & 7,913 & 3.8 \\
\hline 490 & HEPA Filters & 63,340 & 8.9 & $1,079,186$ & 4.4 & 7,488 & 3.5 \\
\hline 2 & Sludge-2nd Stage . & 46,351 & 6.5 & $3,385,472$ & 13.8 & 1,937 & 0.9 \\
\hline 1 & Sludge-1st Stage & 44,057 & 6.2 & $3,073,238$ & 12.5 & 30,481 & 14.4 \\
\hline 3 & Grease & 30,829 & 4.4 & $2,228,119$ & 9.1 & 1,921 & 0.9 \\
\hline 374 & $\begin{array}{l}\text { Concrete, Blacktop, } \\
\text { Dirt, and Sand }\end{array}$ & 23,517 & 3.3 & $1,007,546$ & 4.1 & 647 & 0.3 \\
\hline 336 & Wet Combustibles & 18,554 & 2.6 & 469,649 & 1.9 & $2,509^{\prime}$ & 1.2 \\
\hline 337 & $\begin{array}{l}\text { Plastic (PVC, Teflon, Vinyl) } \\
\text { \& Non-Leaded Rubber }\end{array}$ & 11,948 & 1.7 & 275,252 & 1.1 & 1,877 & 0.9 \\
\hline 441 & Raschig Rings-Unleached & 11,390 & 1.6 & 300,679 & 1.2 & 12,428 & $\$ .9$ \\
\hline 338 & $\begin{array}{l}\text { Insulation \& Chemical Warfare } \\
\text { Service Filter Media }\end{array}$ & 10,402 & 1.5 & 191,054 & .0 .8 & 6,501 & 3.1 \\
\hline 4 & Special Setups & 7,739 & 1.1 & 653,876 & 2.7 & 1,016 & 0.5 \\
\hline \multirow[t]{2}{*}{ Other* } & & 59,639 & 8.4 & $2,090.990$ & 8.5 & 107,236 & 50.8 \\
\hline & TOTAL & 709,497 & 100.0 & $24,546,153$ & 100.0 & 211,148 & 100.0 \\
\hline
\end{tabular}

*For further detail on this category, see Table 2. 
TABLE 2. Generalized Classification of Waste Listed as "Other" in Table 1

\begin{tabular}{|c|c|c|c|c|c|c|c|}
\hline \multirow[b]{2}{*}{ Classification } & \multicolumn{5}{|c|}{$1971-1979$} & \multirow[b]{2}{*}{$\begin{array}{l}\text { Pu Weight } \\
\text { (g) } \\
\end{array}$} & \multirow[b]{2}{*}{$\begin{array}{c}\text { Pu Weight } \\
(\%) \\
\end{array}$} \\
\hline & $\begin{array}{c}\text { Content } \\
\text { Codes } \\
\end{array}$ & $\begin{array}{c}\text { Volume } \\
\text { (cu ft) }\end{array}$ & $\begin{array}{c}\text { Volume } \\
(\%) \\
\end{array}$ & $\begin{array}{c}\text { Weight } \\
\text { (lbs) } \\
\end{array}$ & $\begin{array}{c}\text { Woight } \\
(\%) \\
\end{array}$ & & \\
\hline Glass & $\begin{array}{l}302,370,391 \\
392,393,440 \\
442,464,970\end{array}$ & 16,193 & 2.3 & 443,030 & 1.8 & 10,616 & 5.0 \\
\hline Brick \& Concrete & 371,372 & 5,512 & 0.8 & 180,111 & 0.7 & 3,249 & 1.5 \\
\hline Graphite & $\begin{array}{l}300,301,310 \\
311\end{array}$ & 6,928 & 1.0 & 242,336 & $1: 0$ & 9,465 & 4.5 \\
\hline Sluđges \& Dirt & $\begin{array}{l}241,290,292 \\
375,976,978 \\
990,995\end{array}$ & 6,782 & 1.0 & 282,605 & 1.2 & 3,103 & 1.5 \\
\hline Filter & $\begin{array}{l}335,360,361 \\
376\end{array}$ & 6,628 & 0.9 & 187,472 & 0.8 & 17,307 & 8.2 \\
\hline Metal & $\begin{array}{l}320,481,960 \\
980\end{array}$ & 8,267 & 1.2 & 366,321 & 1.5 & 20,095 & 9.5 \\
\hline Hard \& Soft LSA* & 900,950 & 1,945 & 0.3 & 57,988 & 0.2 & 58 & $\therefore$ \\
\hline Resins & $430,431,432$ & 1,697 & 0.2 & 70,220 & 0.3 & 8,556 & 4.2 \\
\hline Ash & $420,421,422$ & 911 & 0.1 & 27,833 & 0.1 & 18,931 & 9.0 \\
\hline Rubber & $339,460,463$ & 4,557 & 0.6 & 220,696 & 0.9 & 15,619 & 7.4 \\
\hline Salt & $\begin{array}{l}5, \quad 407,410 \\
411\end{array}$ & 219 & 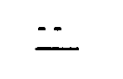 & 12,378 & $\underline{-}$ & 237 & $\cdots$ \\
\hline & TOTAL & 59,639 & 8.4 & $2,090,990$ & 8.5 & 107,236 & 50.8 \\
\hline
\end{tabular}


TABLE 3. Major Waste Contributors of Light Metals-Not Readily Leachable (Content Code 480) 1971-1979

\begin{tabular}{|c|c|c|c|c|c|c|c|}
\hline Prefix & Title & $\begin{array}{r}\text { Volume } \\
\text { (cu ft) }\end{array}$ & $\begin{array}{l}\text { Volume } \\
(\%)\end{array}$ & $\begin{array}{l}\text { Weight } \\
\text { (lbs) }\end{array}$ & $\begin{array}{l}\text { Weight } \\
(\%)\end{array}$ & $\begin{array}{l}\text { Pu Weight } \\
\text { (g) }\end{array}$ & $\begin{array}{l}\text { Pu Weight } \\
\text { (\%) }\end{array}$ \\
\hline 389 & Size Reduction FRP Boxes & 201,464 & 65.2 & $5,644,500$ & $67.3^{\circ}$ & $22,094.2$ & 75.7 \\
\hline 33 & Size Reduction Construction & 32,629 & 10.6 & 767,387 & 9.1 & 68.0 & 0.2 \\
\hline 776 & Size Reduction Non-Retrievable & 19,351 & 6.3 & 425,713 & 5.1 & 286.7 & 1.0 \\
\hline 777 & $\begin{array}{l}\text { Specification Assay Drums- } \\
\text { Bulk Residue }\end{array}$ & 11,480 & 3.7 & 242,010 & 2.9 & 18.4 & 0.1 \\
\hline 771 & $\begin{array}{l}\text { R\&D Drums-Bulk Residue } \\
\text { Pu Cleanup }\end{array}$ & 9,353 & 3.0 & 225,497 . & 2.7 & 923.2 & 3.2 \\
\hline 15 & Non-Specification & 5,271 & 1.7 & 111,150 & 1.3 & 26.3 & 0.1 \\
\hline 11 & $\begin{array}{l}\text { Metallurgical Operations } \\
\text { Casting }\end{array}$ & 3,248 & 1.1 & 65,680 & 0.8 & 1.3 & $\cdots$ \\
\hline 2 & $\begin{array}{l}\text { Non-Specification Recount, } \\
\text { Slow }\end{array}$ & 2,301 & 0.7 & 81,048 & 1.0 & 419.0 & 1.4 \\
\hline Other & & 23,732 & 7.7 & 823,310 & 9.8 & $5,356.7$ & 18.3 \\
\hline & TOTAL & 308,829 & 100.0 & $8,386,295$ & 100.0 & $29,193.8$ & 100.0 \\
\hline
\end{tabular}

TABLE 4. Major Waste Contributors of Dry Combustibles (Content Code 330)

\begin{tabular}{|c|c|c|c|c|c|c|c|}
\hline \multirow[b]{2}{*}{ Prefix } & $\cdots$ & \multicolumn{3}{|c|}{$1971-1979$} & \multirow[b]{2}{*}{$\begin{array}{c}\text { Weight } \\
(\%) \\
\end{array}$} & \multirow[b]{2}{*}{$\begin{array}{l}\text { Pu Weight } \\
\text { (g) }\end{array}$} & \multirow[b]{2}{*}{$\begin{array}{c}\text { Pu Weight } \\
(\%)\end{array}$} \\
\hline & Title & $\begin{array}{r}\text { Volume } \\
\text { (cu ft) } \\
\end{array}$ & $\begin{array}{c}\text { Volume } \\
(\%) \\
\end{array}$ & $\begin{array}{l}\text { Weight } \\
\text { (lbs) } \\
\end{array}$ & & & \\
\hline 389 & Size Reduction FRP Boxes & 55,167 & 75.7 & 919,210 & 65.4 & $5,468.5$ & 69.1 \\
\hline 2 & $\begin{array}{l}\text { Non-Specification Recount, } \\
\text { Slow }\end{array}$ & 3,969 & 5.4 & 91,498 & 6.5 & 459.0 & 5.8 \\
\hline 90 & Solid Waste NMC & 3,844 & 5.3 & 136,949 & 9.7 & 757.0 & 9.6 \\
\hline 15 & Non-Specification & 2,374 & 3.3 & 57,597 & 4.1 & 155.0 & 2.0 \\
\hline 17 & Mtce., Laundry, Utilities & 1,286 & 1.8 & 31,724 & 2.3 & 21.0 & 0.3 \\
\hline 33 & Size Reduction Construction & 803 & 1.1 & 17,905 & 1.3 & 2.9 & $\cdots$ \\
\hline 771 & $\begin{array}{l}\text { R\&D.Drums-Bulk Residue } \\
\text { Pu Cleanup }\end{array}$ & 374 & 0.5 & 27,026 & 1.9 & 197.0 & 2.5 \\
\hline \multirow[t]{3}{*}{ Other } & & 5,085 & 6.9 & 122,888 & 8.8 & $2,852.8$ & 10.7 \\
\hline & TOTAL & 72,902 & .100 .0 & $1,404,797$ & 100.0 & $7,913.2$ & 100.0 \\
\hline & & & $A-4$ & & & & \\
\hline
\end{tabular}


TABLE 5. Major Waste Contributors of Wet Combustibles (Content Code 336)

$$
\text { 1971-1979 }
$$

\begin{tabular}{|c|c|c|c|c|c|c|c|}
\hline Prefix & Title & $\begin{array}{l}\text { Volume } \\
\text { (cu ft) }\end{array}$ & $\begin{array}{l}\text { Volume } \\
(\%) \\
\end{array}$ & $\begin{array}{c}\text { Weight } \\
\text { (lbs) }\end{array}$ & $\begin{array}{c}\text { Weight } \\
(\%) \\
\end{array}$ & $\begin{array}{l}\text { Pu Weight } \\
\text { (g) }\end{array}$ & $\begin{array}{l}\text { Pu Weight } \\
(\%) \\
\end{array}$ \\
\hline 89 & Sizc Reduction Area & 6,817 & 36.7 & 148,527 & 31.6 & 298.0 & 11.9 \\
\hline 2 & Non-Specification Recount, Slow & 3,381 & 18.2 & 83,174 & 17.7 & 743.0 & 29.6 \\
\hline 90 & Solid Waste NMC (Bldg. 750)* & 1,577 & 8.5 & $5.7,108$ & 12.2 & 395.3 & 15.7 \\
\hline 90 & $\begin{array}{l}\text { Waste Mgmt. Compacted Discard } \\
\text { Drums (Bldg. 776)* }\end{array}$ & 1,430 & 7.7 & 51,785 & 11.0 & 435.9 & 17.4 \\
\hline 37 & Labs, Chem Op Supply & 1,194 & 6.4 & 22,358 & 4.8 & 144.0 & 5.7 \\
\hline 17 & Mtce, Laundry, Utilities & 907 & 4.9 & 19,747 & 4.2 & 4.0 & 0.2 \\
\hline 15 & Non-Specification & 545 & 2.9 & 14,488 & 3.1 & 44.1 & 1.7 \\
\hline 1 & Non-Specification Recount, Fast & 472 & 2.5 & 11,172 & 2.4 & 11.0 & 0.4 \\
\hline 12 & Foundry 707 & 332 & 1.8 & 8,255 & 1.8 & 24.0 & 1.0 \\
\hline 389 & Size Reduction FRP Boxes & 224 & 1.2 & 3,980 & 0.8 & 2.1 & 0.1 \\
\hline Other & & 1,675 & 9.0 & 49,055 & 10.4 & 408.2 & $16.3^{-}$ \\
\hline & TOTAL & 18,554 & 100.0 & 469,649 & 100.0 & $2,509.6$ & 100.0 \\
\hline
\end{tabular}

*The original title for prefix 90 came into disuse. After a period of time, the prefix was again used, but for a different title.

TABLE 6. Major Waste Contributors of HEPA Filters (Content Code 490)

\begin{tabular}{|c|c|c|c|c|c|c|c|}
\hline \multirow[b]{2}{*}{ Prefix } & \multicolumn{4}{|c|}{$1971-1979$} & \multirow[b]{2}{*}{$\begin{array}{l}\text { Weight } \\
(\%)\end{array}$} & \multirow[b]{2}{*}{$\begin{array}{l}\text { Pu Weight } \\
\text { (g) }\end{array}$} & \multirow[b]{2}{*}{$\begin{array}{l}\text { Pu Weight } \\
\text { (\%) }\end{array}$} \\
\hline & Title & $\begin{array}{l}\text { Volume } \\
\text { (cu ft) }\end{array}$ & $\begin{array}{c}\text { Volume } \\
(\%) \\
\end{array}$ & $\begin{array}{l}\text { Weight } \\
\text { (lbs) }\end{array}$ & & & \\
\hline 389 & Size Reduction FRP Boxes & 53,424 & 84.4 & 947,766 & 87.8 & $6,343.5$ & 84.7 \\
\hline 776 & Size Redurtionn Non-Retrievable & 4,256 & 6.7 & 44,870 & 4.2 & 363.3 & 4.9 \\
\hline 1371 & Pu Chemistry & 1,904 & 3.0 & 21,460 & 2.0 & 86.0 & 1.1 \\
\hline 33 & Size Reduction Construction & 1,792 & 2.8 & 32,240 & 3.0 & 1.6 & - \\
\hline 771 & $\begin{array}{l}\text { R\&D Drums-Bulk Reșidue } \\
\text { Pu Cleanup }\end{array}$ & 1,268 & 2.0 & 17,706 & 1.6 & 499.0 & 6.0 \\
\hline \multirow[t]{3}{*}{ Üther } & & 696 & 1.1 & 15.144 & 1.4 & 244.6 & 3.3 \\
\hline & TOTAL & 63,340 & 100.0 & $1,079,186$ & 100.0 & $7,488.0$ & 100.0 \\
\hline & & & $A-5$ & & & & \\
\hline
\end{tabular}


TABLE 7. Waste Contributors of Second Stage Sludge (Content Code 2)

\begin{tabular}{|c|c|c|c|c|c|c|c|}
\hline \multirow[b]{2}{*}{ Prefix } & \multirow[b]{2}{*}{ Title } & \multicolumn{3}{|c|}{ 1971-1979 } & \multirow[b]{2}{*}{$\begin{array}{c}\text { Weight } \\
(\%) \\
\end{array}$} & \multirow[b]{2}{*}{$\begin{array}{l}\text { Pu Weight } \\
\text { (g) } \\
\end{array}$} & \multirow[b]{2}{*}{$\begin{array}{c}\text { Pu Weight } \\
(\%)\end{array}$} \\
\hline & & $\begin{array}{l}\text { Volume } \\
\text { (cu ft) }\end{array}$ & $\begin{array}{l}\text { Volume } \\
(\%)\end{array}$ & $\begin{array}{c}\text { Weight } \\
\text { (bs) }\end{array}$ & & & \\
\hline 742 & $\begin{array}{l}\text { Liquid Waste Treatment-2nd } \\
\text { Stage }\end{array}$ & 46,339 & 100.0 & $3,383,501$ & 100.0 & $1,925.9$ & 100.0 \\
\hline 743 & $\begin{array}{l}\text { Liquid Waste Treatment- } \\
\text { Drainage Sludge }\end{array}$ & 8 & $\cdots$ & 1,397 & -- & 1.8 & -- \\
\hline 741 & Liquid Waste Treatment-1st & 4 & -. & 574 & $\cdots$ & 8.9 & $\cdots$ \\
\hline & TOTAL & 46,351 & 100.0 & $3,385,472$ & 100.0 & $1,936.6$ & 100.0 \\
\hline
\end{tabular}

TABLE 8. Waste Contributors of First Stage Sludge (Content Code 1)

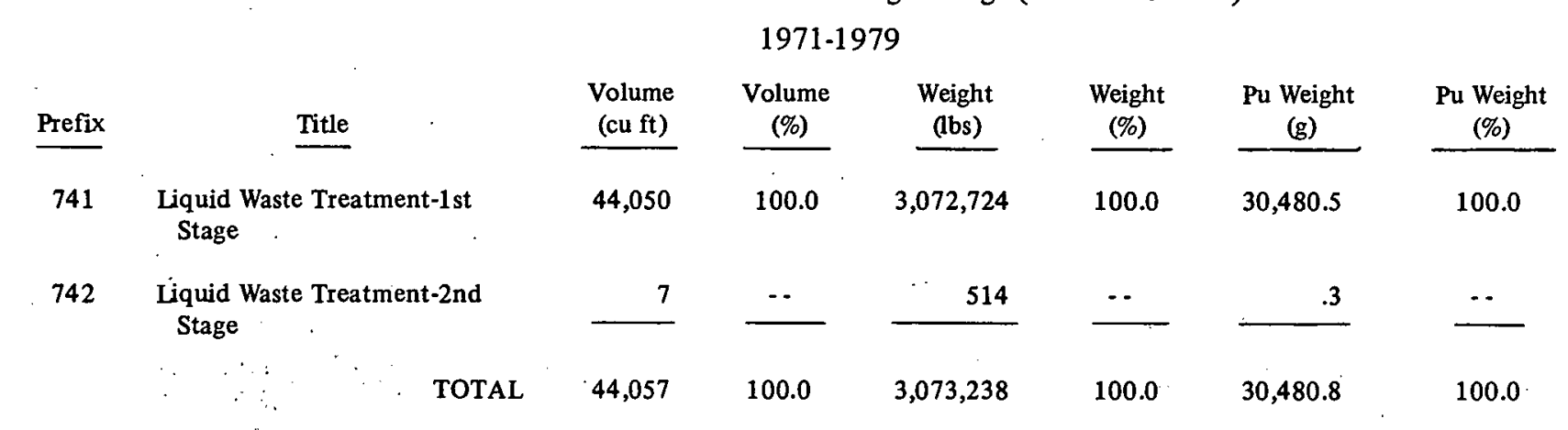

TABLE 9. Waste Contributors of Grease (Content Code 3)

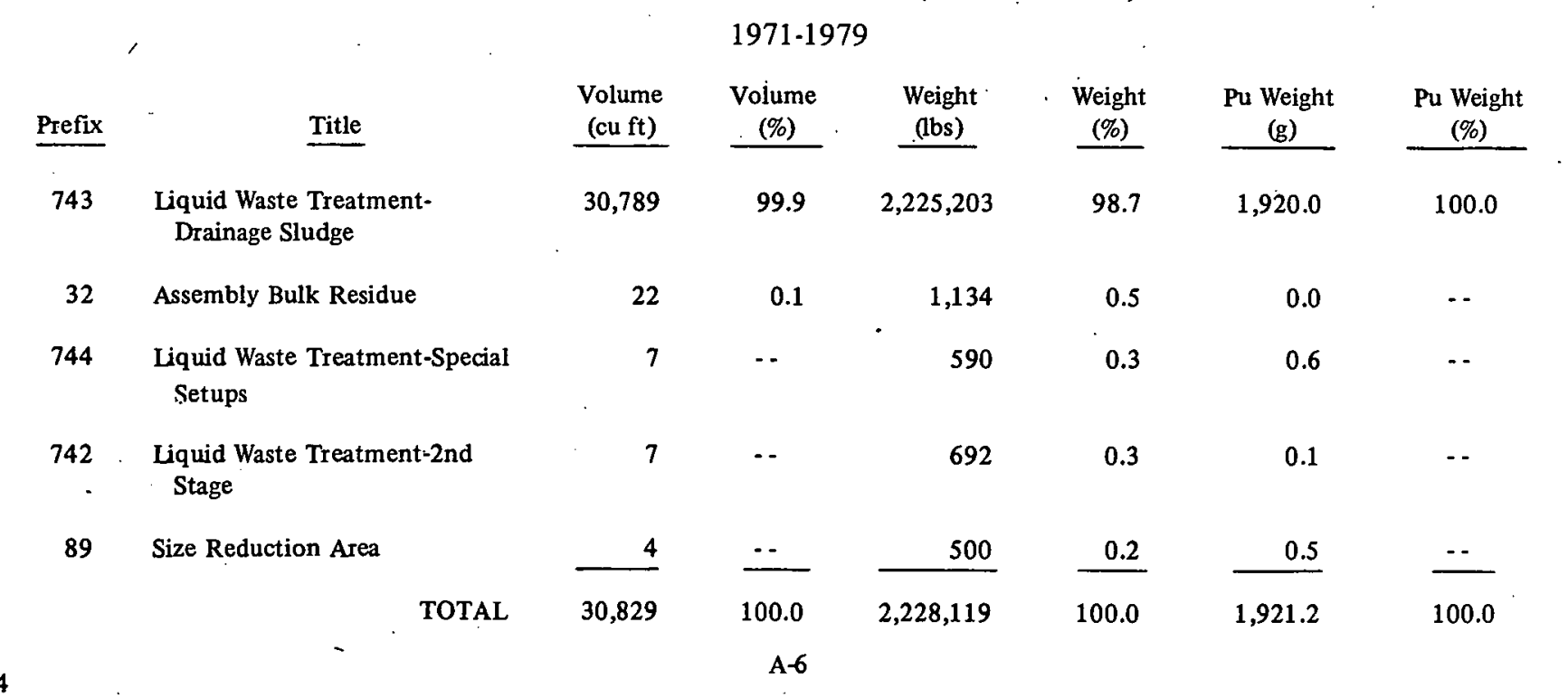


RFP-3186

TABLE 10. Waste Contributor of Special Setups (Content Code 4)

\begin{tabular}{|c|c|c|c|c|c|c|c|}
\hline \multirow[b]{2}{*}{ Prefix } & \multicolumn{7}{|c|}{ 1971-1979 } \\
\hline & Title & $\begin{array}{c}\text { Volume } \\
\text { (cu ft) }\end{array}$ & $\begin{array}{c}\text { Volume } \\
(\%)\end{array}$ & $\begin{array}{c}\text { Weight } \\
\text { (lbs) }\end{array}$ & $\begin{array}{l}\text { Weight } \\
(\%)\end{array}$ & $\begin{array}{c}\text { Pu Weight } \\
\text { (g) }\end{array}$ & $\begin{array}{c}\text { Pu Weight } \\
(\%)\end{array}$ \\
\hline 744 & $\begin{array}{l}\text { Liquid Waste Treatment, Special } \\
\text { Setups }\end{array}$ & 7,739 & 100.0 & 653,876 & 100.0 & $1,016.2$ & 100.0 \\
\hline
\end{tabular}

TABLE 11. Major Waste Contributors of Concrete, Asphalt, Dirt, and Grit (Content Code 374)

\begin{tabular}{|c|c|c|c|c|c|c|c|}
\hline \multirow[b]{2}{*}{ Prefix } & \multicolumn{4}{|c|}{$1971-1979$} & \multirow[b]{2}{*}{$\begin{array}{l}\text { Weight } \\
(\%)\end{array}$} & \multirow[b]{2}{*}{$\begin{array}{l}\text { Pu Weight } \\
\text { (g) }\end{array}$} & \multirow[b]{2}{*}{$\begin{array}{l}\text { Pu Weight } \\
\text { (\%) }\end{array}$} \\
\hline & Title & $\begin{array}{l}\text { Volume } \\
\text { (cu ft) }\end{array}$ & $\begin{array}{c}\text { Volume } \\
(\%) \\
\end{array}$ & $\begin{array}{c}\text { Weight } \\
\text { (lbs) } \\
\end{array}$ & & & \\
\hline 185 & $\begin{array}{l}\text { Contaminated Soil-Lip Area } \\
\text { Side of Pad }\end{array}$ & 16,184 & 68.8 & 747,760 & $\begin{array}{c}74.2 \\
.\end{array}$ & 0.0 & $\cdots$ \\
\hline 33 & Size Reduction Construction & 3,136 & 13.3 & 85,920 & 8.5 & 6.2 & 1.0 \\
\hline 389 & Size Reduction FRP Boxes & 1,792 & 7.6 & 54,220 & 5.4 & 70.2 & 10.9 \\
\hline 2 & $\begin{array}{l}\text { Non-Spectication Recount, } \\
\text { Slow }\end{array}$ & 1,087 & 4.6 & 50,460 & 5.0 & 298.1 & 46.1 \\
\hline 5 & $\begin{array}{l}\text { Non-Specification Raschig } \\
\text { Rings }\end{array}$ & 559 & 2.4 & 20,638 & 2.1 & 271.0 & 41.8 \\
\hline 17 & Mtce., Laundry, Utilities & 265 & 1.1 & 17,321 & 1.7 & 0.0 & - \\
\hline 746 & $\begin{array}{l}\text { Liquid Waste Treatment, } \\
\text { Misc. Waste. }\end{array}$ & 176 & 0.8 & 14,262 & 1.4 & 0.0 & $=$ \\
\hline Other & . & 318 & 1.4 & 16,965 & 1.7 & 1.4 & 0.2 \\
\hline & TOTAL & 23,517 & 100.0 & $1,007,546$ & 100.0 & 646.9 & 100.0 \\
\hline
\end{tabular}


RFP-3186

TABLE 12. Major Waste Contributors of Plastic (PVC, Teflon, Vinyl) and Non-Leaded Rubber (Content Code 337)

\begin{tabular}{|c|c|c|c|c|c|c|c|}
\hline Prefix & Title & $\begin{array}{l}\text { Volume } \\
\text { (cu ft) }\end{array}$ & $\begin{array}{l}\text { Volume } \\
\text { (\%) }\end{array}$ & $\begin{array}{l}\text { Weight } \\
\text { (lbs) }\end{array}$ & $\begin{array}{l}\text { Weight } \\
(\%)\end{array}$ & $\begin{array}{l}\text { Pu Weight } \\
\text { (g) }\end{array}$ & $\begin{array}{l}\text { Pu Weight } \\
\text { (\%) }\end{array}$ \\
\hline 744 & $\begin{array}{l}\text { Liquid Waste Treatment, Special } \\
\text { Setups }\end{array}$ & 3,041 & 25.5 & 54,762 & 19.9 & 37.5 & 2.0 \\
\hline 2 & $\begin{array}{l}\text { Non-Specification Recount, } \\
\text { Slow }\end{array}$ & 1,757 & 14.7 & 42,483 & 15.4 & 588.0 & 31.3 \\
\hline 89 & Size Reduction Area & 1,338 & 11.2 & $.28,242$ & 10.3 & 130.0 & 6.9 \\
\hline 37 & $\begin{array}{l}\text { Analytical Labs, Chemical } \\
\text { Operations, Support Labs }\end{array}$ & 1,250 & 10.5 & 35,631 & 12.9 & 70.0 & 3.8 \\
\hline 17 & Mtce., Laundry, Utilities & 904 & 7.6 & 21,689 & 7.0 & 13.0 & 0.7 \\
\hline 33 & Size Reduction Construction & 448 & 3.7 & 8,480 & 3.1 & 0.6 & $\cdots$ \\
\hline 1 & $\begin{array}{l}\text { Non-Specification Recount; } \\
\text { Fast }\end{array}$ & 382 & -3.2 & 8,804 & 3.2 & $\begin{array}{r}25.0 \\
\vdots \ldots\end{array}$ & 1.3 \\
\hline 776 & $\begin{array}{l}\text { Size Reduction Non-Retrievable } \\
\text { Waste }\end{array}$ & 125 & 1.0 & 9,641 & 3.5 & 261.0 & 13.9 \\
\hline Other & . & 2,703 & 22.6 & 65,520 & 23.8 & 751.7 & 40.1 \\
\hline & TOTAL & 11,948 & 100.0 & 275,252 & 100.0 & $1,876.8$ & 100.0 \\
\hline
\end{tabular}


TABLE 14. Major Waste Contributors of Insulation Chemical Warfare Service Filter Media (Content Code 338)

\begin{tabular}{|c|c|c|c|c|c|c|c|}
\hline \multirow[b]{2}{*}{ Prefix } & \multicolumn{7}{|c|}{ 1971-1979 } \\
\hline & Title & $\begin{array}{l}\text { Volume } \\
\text { (cu ft) }\end{array}$ & $\begin{array}{c}\text { Volume } \\
(\%)\end{array}$ & $\begin{array}{c}\text { Weight } \\
\text { (lbs) }\end{array}$ & $\begin{array}{l}\text { Weight } \\
(\%)\end{array}$ & $\begin{array}{l}\text { Pu Weight } \\
\text { (g) }\end{array}$ & $\begin{array}{l}\text { Pu Weight } \\
\text { (\%) }\end{array}$ \\
\hline 33 & Size Reduction Construction & 6,944 & 66.8 & 123,850 & 64.8 & 9.1 & 0.1 \\
\hline 389 & Size Reduction FRP Boxes & 1,792 & 17.2 & 30,040 & 15.7 & 66.5 & 1.0 \\
\hline 2 & Non-Specification Recount, Slow & 1,172 & 11.3 & 23,417 & 12.3 & $4,010.0$ & 61.7 \\
\hline Other & - & 494 & 4.7 & 13,747 & 7.2 & $2,415.0$ & 37.2 \\
\hline & TOTAL & 10,402 & 100.0 & 191,054 & 100.0 & $6,500.6$ & 100.0 \\
\hline
\end{tabular}


TABLE 15. Content Volumes and Volume Percents by Year (1971-1979)

\begin{tabular}{|c|c|c|c|c|c|c|c|c|}
\hline \multirow[b]{2}{*}{$\begin{array}{c}\text { Content } \\
\text { Code } \\
\end{array}$} & \multicolumn{2}{|c|}{1971} & \multicolumn{2}{|c|}{1972} & \multicolumn{2}{|c|}{1973} & \multicolumn{2}{|c|}{1974} \\
\hline & $\begin{array}{c}\text { Volume } \\
\text { (cu ft) } \\
\end{array}$ & $\begin{array}{c}\text { Volume } \\
(\%) \\
\end{array}$ & $\begin{array}{c}\text { Volume } \\
\text { (cu ft) }\end{array}$ & $\begin{array}{c}\text { Volume } \\
(\%) \\
\end{array}$ & $\begin{array}{c}\text { Volume } \\
\text { (cu ft) } \\
\end{array}$ & $\begin{array}{c}\text { Volume } \\
(\%) \\
\end{array}$ & $\begin{array}{c}\text { Volume } \\
(\mathrm{cu} f t)\end{array}$ & $\begin{array}{c}\text { Volume } \\
(\%) \\
\end{array}$ \\
\hline 480 & 42,226 & 66.1 & 65,762 & 46.9 & 58,793 & 48.7 & 59,944 & 53.7 \\
\hline 330 & 4,422 & 6.9 & 3,919 & 2.8 & 3,545 & 2.9 & 3,654 & 3.3 \\
\hline 490 & 4,965 & 7.8 & 12,151 & 8.7 & 10,818 & 9.0 & 10,871 & 9.7 \\
\hline 2 & 4,459 & 7.0 & 8,388 & 6.0 & 6,626 & 5.5 & 9,323 & 8.4 \\
\hline 1 & 1,916 & 3.0 & 9,298 & 6.6 & 8,424 & 7.0 & 6,766 & 6.1 \\
\hline 3 & 1,363 & 2.1 & 8,078 & 5.8 & 4,400 & 3.6 . & 4,223 & 3.8 \\
\hline 374 & -- & -. & -- & $\ldots$ & 2,842 & 1.3 & 2,081 & 1.9 \\
\hline 336 & 1,209 & 1.9 & 10,670 & 7.6 & 3,265 & 2.7 & 1,599 & 1.4 \\
\hline 337 & 391 & 0.6 & 4,808 & 3.4 & 3,223 & 2.7 & 1,271 & 1.1 \\
\hline 441 & $\cdots$ & -- & 384. & 0.3 & 1,778 & 1.5 & 295 & 0.3 \\
\hline 338 & - & -- & 239 & 0.2 & 4,972 & 4.1 & 4,734 & 4.2 \\
\hline 4 & 420 & 0.7 & 2,128 & 1.5 & 1,187 & 1.0 & 722 & 0.6 \\
\hline Other " & 2,525 & 3.9 & 14,356 & 10.2 & 10,839 & 9.0 & 6,232 & 5.5 \\
\hline TOTAL & 63,896 & 100.0 & 140,181 & 100.0 & 120,712 & 100.0 & 111,715 & 100.0 \\
\hline
\end{tabular}

\begin{tabular}{|c|c|c|c|c|c|c|c|c|c|c|}
\hline \multirow[b]{2}{*}{$\begin{array}{c}\text { Content } \\
\text { Code } \\
\end{array}$} & \multicolumn{2}{|c|}{1975} & \multicolumn{2}{|c|}{1976} & \multicolumn{2}{|c|}{1977} & \multicolumn{2}{|c|}{1978} & \multicolumn{2}{|c|}{1979} \\
\hline & $\begin{array}{l}\text { Volume } \\
\text { (cu ft) }\end{array}$ & $\begin{array}{c}\text { Volume } \\
(\%)\end{array}$ & $\begin{array}{l}\text { Volume } \\
\text { (cu ft) }\end{array}$ & $\begin{array}{c}\text { Vulunine } \\
(\%) \\
\end{array}$ & $\begin{array}{l}\text { Volume } \\
\text { (cu ft) }\end{array}$ & $\begin{array}{l}\text { Volume } \\
(\%)\end{array}$ & $\begin{array}{l}\text { Volume } \\
\text { (cu ft) }\end{array}$ & $\begin{array}{c}\text { Volume } \\
(\%)\end{array}$ & $\begin{array}{l}\text { Volume } \\
\text { (cu ft) }\end{array}$ & $\begin{array}{c}\text { Volume } \\
(\%) \\
\end{array}$ \\
\hline 480 & 25,741 & 38.9 & 27,056 & 38.0 & 14,265 & 19.6 & 10,643 & 23.3 & 4,399 & 25.4 \\
\hline 330 & 3,879 & 5.9 & 11,499 & 16.1 & 20,904 & 28.7 & 14,174 & 31.0 & 6,906 & 39.9 \\
\hline 490 & 9,527 & 14.4 & 4,480 & 6.3 & 4,032 & 5.5 & 4,480 & 9.8 & 2,016 & 11.6 \\
\hline 2 & 5,314 & 8.0 & 4,260 & 6.0 & $.3,346$ & 4.6 & 3,346 & 7.3 & 1,289 & 7.5 \\
\hline 1 & 5,328 & . 8.1 & 4,179 & 5.9 & 3,781 & 5.2 & 3,803 & 8.3 & 562 & 3.2 \\
\hline 3 & 3,626 & 5.5 & 2,661 & 3.7 & 2,462 & 3.4 & 3,486 & 7.7 & 530 & 3.1 \\
\hline 374 & 935 & 1.4 & 4,172 & 5.9 & 13,487 & 18.6 & $-\cdot$ & $\cdots$ & -. & -. \\
\hline 336 & 848 & .1 .3 & 703 & 1.0 & 140 & 0.2 & 96 & 0.2 & 24 & 0.1 \\
\hline 337 & 803 & 1.2 & 671 & 0.9 & 560 & 0.8 & 221 & 0.5 & $\cdots$ & - \\
\hline 441 & 3,346 & 5.1 & 2,484 & 3.5 & 2,034 & 2.8 & 1,069 & 2.3 & - & $\cdots$ \\
\hline 338 & 265 & 0.4 & 192 & 0.3 & $\cdots$ & $\cdots$ & $\cdots$ & $\cdots$ & $\cdots$ & -. \\
\hline 4 & 774 & 1.1 & 678 & 1.0 & 1,135 & 1.6 & 649 & 1.4 & 46 & 0.3 \\
\hline Other & 5,745 & 8.7 & 8,154 & 11.4 & 6,558 & 9.0 & 3,688 & 8.1 & 1,542 & 8.9 \\
\hline TOTAL & 66,131 & 100.0 & 71,190 & 100.0 & 72,704 & 100.0 & 45,654 & 100.0 & 17,314 & 100.0 \\
\hline
\end{tabular}


TABLE 16. Content Weight and Weight Percent by Year (1971-1979)

\begin{tabular}{|c|c|c|c|c|c|c|c|c|}
\hline \multirow[b]{2}{*}{$\begin{array}{c}\text { Content } \\
\text { Code }\end{array}$} & \multicolumn{2}{|c|}{1971} & \multicolumn{2}{|c|}{1972} & \multicolumn{2}{|c|}{1973} & \multicolumn{2}{|c|}{1974} \\
\hline & $\begin{array}{c}\text { Weight } \\
\text { (lbs) }\end{array}$ & $\begin{array}{c}\text { Weight } \\
(\%)\end{array}$ & $\begin{array}{c}\text { Weight } \\
\text { (lbs) }\end{array}$ & $\begin{array}{c}\text { Weight } \\
(\%)\end{array}$ & $\begin{array}{c}\text { Weight } \\
\text { (Ibs) }\end{array}$ & $\begin{array}{c}\text { Weight } \\
(\%)\end{array}$ & $\begin{array}{c}\text { Weight } \\
\text { (lbs) }\end{array}$ & $\begin{array}{c}\text { Weight } \\
(\%)\end{array}$ \\
\hline 480 & 871,640 & 49.1 & $2,357,959$ & 38.9 & $1,545,343$ & 38.8 & $1,516,339$ & 40.2 \\
\hline 330 & 101,011 & 5.7 & 113,803 & 1.9 & 102,347 & 2.6 & 98,993 & 2.6 \\
\hline 490 & 53,900 & 3.0 & 215,117 & 3.6 & 189,577 & 4.7 & 182,320 & 4.8 \\
\hline 2 & 337,371 & 19.0 & 745,193 & 12.4 & 464,013 & 11.7 & 672,906 & 17.8 \\
\hline 1 & 129,460 & 7.3 & 756,834 & 12.6 & 566,689 & 14.2 & 470,869 & 12.4 \\
\hline 3 & 107,350 & 6.0 & 685,042 & 11.4 & 316,160 & 7.9 & 293,268 & 7.8 \\
\hline 374 & - & - & - & $\cdots$ & 84,186 & 2.1 & 68,465 & 1.8 \\
\hline 336 & 28,080 & 1.6 & 245,717 & 4.1 & 95,956 & 2.4 & 48,745 & 1.3 \\
\hline 337 & 8,823 & 0.5 & 115,126 & 1.9 & $7,0,823$ & 1.8 & 29,030 & 0.8 \\
\hline 441 & $\cdots$ & $\cdots$ & 14,338 & 0.2 & 51,754 & 1.3 & 7,561 & 0.2 \\
\hline 338 & -- & - & 4,485 & 0.1 & 90,043 & 2.2 & 85,429 & 2.3 \\
\hline 4 & 35,636 & 2.0 & 231,981 & 3.9 & 88,169 & 2.2 & 55,382 & 1.5 \\
\hline Other & 102,268 & 5.8 & 539,095 & 9.0 & 316,640 & 8.1 & 243,347 & 6.5 \\
\hline TOTAL & $, 775,539$ & 100.0 & $6,024,690$ & 100.0 & $3,981,700$ & 100.0 & $3,772,654$ & 100.0 \\
\hline
\end{tabular}

1975

\begin{tabular}{|c|c|c|c|c|}
\hline $\begin{array}{c}\text { Content } \\
\text { Code } \\
\end{array}$ & $\begin{array}{l}\text { Weight } \\
\text { (lbs) }\end{array}$ & $\begin{array}{c}\text { Weight } \\
(\%) \\
\end{array}$ & $\begin{array}{c}\text { Weight } \\
\text { (lbs) }\end{array}$ & $\begin{array}{c}\text { Weight } \\
(\%) \\
\end{array}$ \\
\hline 480 & 664,859 & 28.5 & 668,079 & 29.0 \\
\hline 330 & 88,339 & 3.8 & 221,080 & 9.6 \\
\hline 490 & 165,072 & 7.1 & 85,420 & 3.7 \\
\hline 2 & 354,131 & 15.2 & 279,865 & 12.2 \\
\hline 1 & 362,299 & 15.5 & 291,039 & 12.6 \\
\hline 3 & 242,117 & 10.4 & 169,621 & 7.4 \\
\hline 374 & 56,559 & 2.4 & 143,439 & 6.2 \\
\hline 336 & 26,099 & 1.1 & 17,890 & 0.8 \\
\hline 337 & 17,566 & 0.8 & 14,877 & 0.6 \\
\hline 441 & 84,606 & 3.6 & 62,731 & 2.7 \\
\hline 338 & 5,335 & 0.2 & 5,762 & 0.3 \\
\hline 4 & 56,724 & 2.4 & 50,025 & 2.2 \\
\hline Other & 212,054 & 9.0 & 292,209 & 12.7 \\
\hline TOTA & $, 335,760$ & 100.0 & $, 302,037$ & 100.0 \\
\hline
\end{tabular}

1977

\begin{tabular}{|c|c|}
\hline $\begin{array}{c}\text { Weight } \\
\text { (lbs) }\end{array}$ & $\begin{array}{c}\text { Weight } \\
(\%)\end{array}$ \\
\hline 373,129 & 15.3 \\
\hline 335,873 & 13.8 \\
\hline 71,280 & 2.9 \\
\hline 223,044 & 9.2 \\
\hline 260,363 & 10.7 \\
\hline 151,344 & 6.2 \\
\hline 654,897 & 26.9 \\
\hline 4,452 & 0.2 \\
\hline 13,480 & 0.5 \\
\hline 51,336 & 2.1 \\
\hline$\cdots$ & $\cdots$ \\
\hline 82,477 & 3.4 \\
\hline 214,115 & 8.8 \\
\hline
\end{tabular}

1978

\begin{tabular}{ccc}
\hline $\begin{array}{c}\text { Weight } \\
\text { (lbs) }\end{array}$ & & $\begin{array}{c}\text { Weight } \\
(\%)\end{array}$ \\
\cline { 1 - 1 } 289,347 & & 20.0 \\
227,771 & & 15.7 \\
81,260 & 5.6 \\
225,583 & & 15.6 \\
202,157 & & 14.0 \\
222,738 & & 15.4 \\
.- & & -- \\
2,517 & 0.2 \\
5,527 & 0.4 \\
28,353 & 2.0 \\
.- &.- \\
47,872 & 3.3 \\
113,395 & 7.8 \\
\hline $1,446,520$ & 100.0
\end{tabular}

1979

\begin{tabular}{cc}
\hline $\begin{array}{c}\text { Weight } \\
\text { (bs) }\end{array}$ & $\begin{array}{c}\text { Weight } \\
(\%)\end{array}$ \\
99,600 & 21.2 \\
115,580 & 24.5 \\
35,240 & 7.5 \\
82,841 & 17.6 \\
33,528 & 7.2 \\
40,479 & 8.6 \\
$\ldots$ &.- \\
193 & 0.0 \\
.- & $\ldots$ \\
-- &.- \\
$\ldots$ &.. \\
5,610 & 1.2 \\
57,867 & 12.2 \\
\hline 470,938 & 100.0
\end{tabular}


TABLE 17. Content Plutonium Weight and Plutonium Weight Percent by Year (1971-1979)

\begin{tabular}{|c|c|c|c|c|c|c|c|c|}
\hline \multirow{2}{*}{$\begin{array}{l}\text { Content } \\
\text { Code }\end{array}$} & \multicolumn{2}{|c|}{1971} & \multicolumn{2}{|c|}{1972} & \multicolumn{2}{|c|}{1973} & \multicolumn{2}{|c|}{1974} \\
\hline & $\begin{array}{l}\text { Plutonium } \\
\text { (g) }\end{array}$ & $\begin{array}{l}\text { Plutonium } \\
\text { (wt \%) }\end{array}$ & $\begin{array}{l}\text { Plutonium } \\
\cdot(\mathrm{g})\end{array}$ & $\begin{array}{l}\text { Plutonium } \\
\text { (wt \%) }\end{array}$ & $\begin{array}{l}\text { Plutonium } \\
\text { (g) }\end{array}$ & $\begin{array}{l}\text { Plutonium } \\
\text { (wt \%) }\end{array}$ & $\begin{array}{l}\text { Plutonium } \\
\text { (g) }\end{array}$ & $\begin{array}{l}\text { Plutonium } \\
\text { (wt \%) }\end{array}$ \\
\hline 480 & 348.0 & 8.3 . & $9,386.0$ & 22.5 & $9,545.4$ & 27.7 & $6,628.0$ & 22.9 \\
\hline 330 & 295.0 & 7.1 & 543.4 & 1.3 & 372.1 & 1.1 & 425.9 & 1.5 \\
\hline 490 & 592.3 & 14.2 & $1,492.2$ & 3.6 & 698.9 & 2.0 & $1,040.0$ & 3.6 \\
\hline 2 & 96.0 & 2.3 & 396.9 & 1.0 & 269.7 & 0.8 & 379.4 & 1.3 \\
\hline 1 & $2,309.5$ & 55.4 & $11,472.4$ & 27.5 & $3,767.7$ & 10.9 & $3,230.8$ & $11.2^{\circ}$ \\
\hline 3 & 80.5 & 1.9 & 866.5 & 2.1 & 613.3 & 1.8 & 151.0 & 0.5 \\
\hline 374 & -- & - & -- & $\cdots$ & 97.6 & 0.3 & 520.6 & 1.8 \\
\hline 336 & 78.1 & 1.9 & 828.0 & 2.0 & 563.0 & 1.6 & 275.3 & 1.0 \\
\hline 337 & 17.7 & 0.4 & 728.6 & 1.7 & 529.0 & 1.5 & 187.5 & 0.6 \\
\hline 441 & $\cdots$ & $\cdots$ & 390.0 & 0.9 & $4,583.0$ & 13.3 & 557.0 & 1.9 \\
\hline 338 & $\because$ & $\cdots$ & 27.0 & 0.1 & $1,948.6$ & 5.7 & $2,152.0$ & 7.4 \\
\hline 4 & 58.2 & 1.4 & 342.6 & 0.8 & 193.4 & 0.6 & 118.7 & 0.4 \\
\hline Other & 295.0 . & 7.1 & $\underline{15,256.1}$ & 36.5 & $11,290.4$ & 32.7 & $13,291.4$ & 45.9 \\
\hline TOTAL & $4,170.3$ & 100.0 & $41,729.7$ & 100.0 & $34,472.6$ & 100.0 & $28,957.6$ & 100.0 \\
\hline
\end{tabular}

\begin{tabular}{|c|c|c|c|c|c|c|c|c|c|c|}
\hline \multirow[b]{2}{*}{$\begin{array}{c}\text { Content } \\
\text { Code }\end{array}$} & \multicolumn{2}{|c|}{1975} & \multicolumn{2}{|c|}{1976} & \multicolumn{2}{|c|}{1977} & \multicolumn{2}{|c|}{1978} & \multicolumn{2}{|c|}{1979} \\
\hline & $\begin{array}{l}\text { Plutonium } \\
\text { (g) }\end{array}$ & $\begin{array}{l}\text { Plutonium } \\
\text { (wt \%) }\end{array}$ & $\begin{array}{l}\text { Plutonium } \\
\text { (g) }\end{array}$ & $\begin{array}{l}\text { Plutonium } \\
\text { (wt \%) }\end{array}$ & $\begin{array}{l}\text { Plutonium } \\
(\mathrm{g})\end{array}$ & $\begin{array}{c}\text { Plutonium } \\
\text { (wt. \%) }\end{array}$ & $\begin{array}{l}\text { Plutonium } \\
\text { (g) } \\
\end{array}$ & $\begin{array}{c}\text { Plutonium } \\
\text { (wt \%) }\end{array}$ & $\begin{array}{l}\text { Plutonium } \\
\text { (g) }\end{array}$ & $\begin{array}{l}\text { Plutonium } \\
\text { (wt \%) }\end{array}$ \\
\hline 480 & 885.4 & 3.3 & 550.3 & 2.4 & $1,270.1$ & 3.5 & 457.3 & 4.1 & 123.3 & .2 .5 \\
\hline 330 & 436.7 & 1.6 & $1,236.6$ & 5.3 & $2,684.7$ & 7.5 & 987.2 & 8.9 & 931.6 & 18.9 \\
\hline 490 & 835.6 & 3.1 & $1,142.1$ & 4.9 & 656.6 & 1.8 & 959.7 & 8.7 & 70.0 & 1.4 \\
\hline 2 & 216.3 & 0.8 & 188.7 & 0.8 & 181.6 & 0.5 & 155.5 & 1.4 & 52.2 & 1.1 \\
\hline 1 & $3,283.2$ & 12.3 & $2,502.2$ & 10.7 & $1,536.6$ & 4.3 & $2,025.1$ & 18.3 & 353.3 & 7.2 \\
\hline 3 & 82.2 & 0.3 & 79.6 & 0.3 & 39.2 & 0.1 & 8.9 & 0.1 & 0.0 & 0.0 \\
\hline 374 & 23.4 & 0.1 & 5.3 & $\cdots$ & 0.0 & $\therefore$ & $\cdots$ & -- & $\cdot-$ & $\cdots$ \\
\hline 336 & 431.5 & 1.6 & 170.1 & 0.7 & 121.0 & 0.3 & 41.6 & 0.4 & 0.0 & 0.0 \\
\hline 337 & 112.6 . & .0 .4 & 58.7 & 0.3 & 169.3 & 0.5 & 73.4 & 0.7 & $\cdots$ & $-\cdot$ \\
\hline 441 & $5,180.5$ & 19.4 & 924.0 & 4.0 & 478.0 & 1.3 & 315.0 & 2.9 & .. & -- \\
\hline 338 & $1,278.0$ & 4.8 & $1,095.0$ & 4.7 & -. & $\cdots$ & - & $\cdots$ & $\cdots$ & $-\cdot$ \\
\hline 4 & 133.3 & 0.5 & 83.3 & 0.4 & 55.4 & 0.2 & 27.3 & 0.2 & 4.0 & 0.1 \\
\hline Other & $13 ; 829.6$ & $51.8^{\circ}$ & $15,295.4$ & 65.5 & $\underline{28,598.2}$ & $80.0^{\circ}$ & $.5,993.0$ & 54.3 & 3,386.7 & 68.8 \\
\hline TOTAL & $26,728.3$ & 100.0 & $23,331.3$ & 100.0 & $35,790.7$ & 100.0 & $11,044.0$ & 100.0 & $4,921.1$ & 100.0 \\
\hline
\end{tabular}




\section{APPENDIX B}

\section{Rocky Flats Content Codes and Descriptions}

Appendix B identifies the content codes used to describe TRU waste shipped from Rocky Flats to INEL for storage from June 1971 to June 1979. Also included in the appendix is a brief description of the waste code and the area in which it originated.

Content Code 1 - First Stage Sludge

Plutonium recovery liquid wastes are treated with chemicals to precipitate radioactive elements in Building 774. The resulting sludge is filtered and discharged into 55-gal drums with cement being added to ensure that no free liquid is present.

Content Code 2 - Second Stage Sludge

Radioactive high-nitrate wastes are mixed with the first stage effluent along with chemicals or coagulants to precipitate the radioactive contaminants. The resulting sludge is filtered and packaged in 55-gal drums. This process is called the "batch" process.

Radioactive low-nitrate wastes are treated in a continuous process that is similar to the batch process in treatment, filtration, and packaging. Effluent from the first stage sludge is not added to this process.

Content Code 3 - Grease

Organic wastes such as lathe coolant are mixed with solidifying agents to form a dry solid. The solid is discharged into 55-gal drums.

Content Code 4 - Special Setups Contaminated liquid wastes that are not compatible with chemical precipitation and evaporation treatments are made basic, if necessary, and added to a cement absorbent mixture in 5.5 -gal drums.

Content Code 5 - Evaporator Salts

High-nitrate wastes are concentrated in solar evaporation ponds and sent to the Building 774 evaporator. The liquids are then concentrated and dried on steam-heated drums, which results in a salt residue.

Content Code 241 - Americium Process Residue

Information on this content code was unattainable.

Content Code 290 - Filter Sludge

This category is a sludge type residue from the incinerator drum filter and various filter plenums. This waste originates from all plutonium areas.

Contenl Code 292 - Cemented Sludge

This category consists of miscellaneous sludges produced on-site, which have been packaged in drums with cement added as an absorbent. 
Content Code 300 - Graphite Molds

Graphite is used as the mold material in casting plutonium metal. Used casting molds make up this category. This waste originates in the plutonium foundry.

Content Code 301 - Graphite Cases

Graphite cases are a part of the mold used in casting plutonium metal. The waste originates in the plutonium foundry.

Content Code 302 and 464 - Benelex and Plexiglass

Benelex and plexiglass are used in all areas as neutron radiation shielding around glove boxes.

Content Code 310 - Graphite, Pulverized or Fines

This category consists of graphite that has been pulverized; it originates from the Plutonium Recovery area.

Content Code 311 - Graphite Heels

Pulverized graphite is passed through the acid dissolution process with the remaining residue being classified as Graphite Heel. This waste originates in the Plutonium Recovery area.

Content Code 320. - Heavy Non-SS* Metal (Ta, W, Pt, Pb)

This category consists mainly of used tantalum crucibles, funnels, and inserts from casting plutonium metal. This waste originates from the Foundry and Molten Salt areas.

Content Code 330 - Combustibles, Dry

Mainly dry rags and paper make up this category. This waste originates from all areas that have plutonium.

Content Code 335 - Absolute Drybox Filters

This waste category originates from all plutonium areas and consists of 8 " $\times 8^{\prime \prime}$ wooden frames with asbestos type filter media. These filters are used to remove airborne particulates in glove-box systems.

Content Code 336 - Combustibles, Wet

All plutonium areas generate this waste category, which consists primarily of paper saturated with decontamination solution and/or rags that may contain nitric acid from inside the glove boxes.

Content Code 337 - Plastics (Teflon, PVC, Vinyl, etc.) and Non-Leaded Rubber

This category consists of plastics, bags, sample vials, and plastic sheeting used to line decontamination enclosures and dryboxes. This waste originates from all plutonium areas.

Content Code 338 and 360 - Insulation

The asbestos type material that is used as a heat shield around furnaces and steam pipes and filter media is included. This waste originates from all plutonium areas.

Content Code 339 - Leaded Drybox Gloves and Other Leaded Material

This category is made up mostly of heavy-leaded rubber gloves that are used in the access ports of glove boxes. All plutonium areas generate this waste category.

${ }^{*}$ SS $=$ Source and Special Material. 
Content Code $360-($ see Code 338$)$

Content Code 361 - Insulation Heel

Information on this content code was unattainable.

Content Code 370 - Leco Crucibles

Leco crucibles are small ceramic crucibles used for laboratory analysis. This waste category originates from the plutonium laboratory.

Content Code 371 - Firebrick

Firebrick is plutonium-contaminated brick used to line the recovery incinerator. This category is generated from the Plutonium Recovery area.

\section{Content Code 372 - Grit}

Tiny particles used to grit-blast non-stainless steel metal items. This method is no longer used. The Plutonium Recovery area generated this waste category.

Content Code 374 - Blacktop, Concrete, Dirt, and Sand

The entire plant site generates this category as a result of spills.

Content Code 375 - Oil Dri (Trade Name)

Oil Dri is an absorbent clay used primarily in the bottom of 55 -gal drums to absorb liquid that could leak through a ruptured polyethylene bag. The Plutonium Recovery area is responsible for the origin of this category.

Content Code 376 - Cemented Insulation and Filter Media

Insulation and filter media is cemented to ensure against moisture and pressurization.

Content Code 391 - Unpulverized Sand and Crucible

This category is made up of magnesium oxide crucibles and sand generated when plutonium fluoride is reduced to plutonium metal in the reduction furnaces. The Plutonium Recovery area is the originator of this category.

Content Code 392 - Unpulverized Slag and Crucible

This category consists of a mixture of slag, cruciblc, and sand generated when plutonium fluoride is reduced to plutonium metal in the reduction furnace. The Plutonium Recovery area is where this category is generated.

Content Code 393 - Sand, Slag, and Crucible Heel

The Plutonium Recovery area is the originator of this category. After the buttons are broken out of their crucibles, the crucibles are returned to the dissolution lines for recovery of the plutonium. A crucible that does not dissolve is termed a "sand, slag, and crucible heel."

Content Code 407 - Molten Salt, $8 \%$ Unpulverized

Salt consisting of sodium chloride, potassium chloride, and $8 \%$ magnesium chloride. These salts are used to pyrochemically reniuve americium from plutonium metal. The Molten Salt area is the originator of this category. 
Content Code 410 - Molten Salt, $30 \%$ Pulverized

The description of this category is the same as Content Code 407, except that the magnesium chloride percentage is $30 \%$. The Molten Salt area is also the originator of this category.

Content Code 411 - Electrorefining Salt

This salt consists of sodium chloride and potassium chloride with $8 \%$ magnesium chloride. The salt is used to pyrochemically remove all types of impurities from plutonium metal. The Electrorefining Facility is responsible for originating this category.

Content Code 420 - Incinerator Ash, Virgin

Combustible plutonium-bearing residues are burned in the Recovery Facility incinerator with the ash residue making up this category. The ash is jaw crushed and ball milled prior to removal from the glove box. The Plutonium Recovery area is the originator of this category.

\section{Content Code 421 - Ash Heels}

The heel is the residue remaining after the incinerator ash has received one or more passes through the dissolution process. The Plutonium Recovery area is the originator of this category.

Content Code 422 - Soot

This category is generated from the incinerator in the Plutonium Recovery area. This airborne fly ash material accumulated in the offgas system and is generated only when the offgas system is disassembled and cleaned.

Content Code 430 - Resin, Unleached

This category originates from ion columns in the Plutonium Recovery area and is unleached.

Content Code 431 - Resin, Leached

This category originates from the Plutonium Recovery area where the ion column resin has been leached in water to recover the plutonium.

Content Code 432 - Resin, Cemented

This category is made up of ion column resin that has been washed in water and mixed with a cementing agent to solidify the material. This waste originates from the Plutonium Recovery area.

Content Code 440 - Glass (Except Raschig Rings)

This category is made up of glassware, primarily from the analytical lab, and glass vessels from the recovery facility glove boxes. All plutonium areas are responsible for generating this waste.

Content Code 441 - Unleached Raschig Rings Only

These high boron content glass rings are used as a neutron poison in storage tanks that contain plutonium solution. All plutonium areas generated this waste category. 
Content Code 442 - Leached Raschig Rings

These high boron content glass rings have been leached with nitric acid to remove the plutonium residue. All plutonium areas generate this category.

Content Code 460 - Washables

Information on this category was unattainable.

Content Code 463 - Drybox Gloves

This content code has been incorporated into Content Code 339.

Content Code 464 - (see Code 302)

Content Code 480 - Light Non-SS Metal*, (Fe, Cu, Al, Stainless Steel, etc.)

Not Prepared for Leaching

This category consists of contaminated metals, primarily stainless steel that has been removed from all plutonium areas.

Content Code 481 - Light Non-SS Metal*, (Fe, $\mathrm{Cu}, \mathrm{Al}$, Stainless Steel, etc.)

Prepared for Leaching

This category consists of contaminated metal that has been cut into pieces suitable for cleaning. The Size Reduction area is the originator of this waste category.

Content Code 490 - HEPA Filters

This category consists of High Efficiency Particulate Air (HEPA) filters that are used in the exhaust systems of plutonium buildings to remove airborne particles. All plutonium areas contribute to this category.

Content Code 900 - Soft-LSA Non-Plutonium

This category consists of paper and plastics that have been contaminated as follows:

a. Uranium and Thorium or chemical concentrates.

b. Material in which the activity is essentially uniformly distributed and in which the estimated concentration per gram of contents does not exceed

1. 0.0001 millicuries of Group I radionuclides (e.g., U-230, U-233, U-234, tI-232), nr

2. 0.005 millicuries of Group II radionuclides (e.g., U-230, U-233, U-234, U-236), or

3. 0.3 millicuries of Group III or IV radionuclides (e.g., tritium, U-235, U-238, natural uranium, europium, plutonium)

c. Nonradioactive objects externally contaminated with radioactive material, provided that the radioactive material is not readily dispersible and the surface contamination, when averaged over an area of one square meter, does not exceed 0.0001 millicuries per square centimeter of Group I radionuclides or 0.001 millicuries per square centimeter of other radionuclides.

Content Code 950 - LSA Metal and Glass

This category consists of any metals or glass that have become contaminated as follows:

a. Contaminated with uranium or thorium ores or their chemical concentrates.

*SS means Source and Special Material, a term that has been replaced by the term, Nuclear Material. 
b. Material in which the activity is essentially uniformly distributed and in which the estimated average concentration does not exceed

1. 0.0001 millicuries of Group I radionuclides (e.g., americium, plutonium, U-232), or

2. 0.005 millicuries of Group II radionuclides (e.g., U-230, U-233, U-234, U-236), or

3. 0.3 millicuries of Group III or IV radionuclides (e.g., tritium, U-235, U-238, natural uranium, europium, plutonium)

c. Nonradioactive objects externally contaminated with radioactive material, provided that the radioactive material is not readily dispersible and the surface contamination, when averaged over an area of one square meter, does not exceed 0.0001 millicuries per square centimeter of Group I radionuclides or 0.001 millicuries per square centimeter of other radionuclides.

Content Code 960 - Non-Plutonium Concrete and Asphalt

This category is made up of concrete and asphalt from areas considered to be "suspect."

Content Code 970 - Non-Plutonium Wood and Benelex

This category consists of wood and benelex from areas that are considered to be "suspect."

Content Code 976 - 776 Process Sludge

This category consists of sludge retrieved from the process tanks behind Building 776 .

Content Code 978 - 778 Laundry Sludge

This content code consists of sludge from laundry waste.

Content Code 980 - Non-Plutonium Equipment

This category consists of discarded equipment from non-plutonium areas.

Content Code 990 - Soil 774

This category consists of soil taken from around Building 774 .

Content Code 995 - Sludge-Building 995

Sanitary sludge from Building 995 makes up this category. 